\title{
Maximum quantum yield of photosystem II to assist in the measurement of herbicide selectivity in popcorn
}

\author{
Ismael L. J. Freitas*, Weverton P. Rodrigues, Antonio T. Amaral. Júnior, Silvério P. Freitas, \\ Reynaldo T. Amim, Cássio Vittorazzi \& Jalille A. A. Freitas
}

\begin{abstract}
The objective of this study was to evaluate the selectivity/phytotoxicity of herbicides (mesotrione, nicosulfuron, and tembotrione) using the maximum quantum yield of photosystem II associated with biometric analyses. The experiment was conducted using three popcorn genotypes (BRS Angela, IAC-125 and UENF-14) and three herbicides (mesotrione, tembotrione and nicosulfuron, and a control treatment "WITH WEEDING?". The quantum yield of photosystem II was obtained through a modulated light portable fluorometer MINI-PAM, from the chlorophyll $a$ fluorescence. Regarding the biometric analyses, the following characteristics were evaluated: a) number medium of ears of the corn, b) grain yield in $\mathrm{kg} \mathrm{ha}^{-1}$, c) average weight of 100 grains, and d) popping expansion. The genotypes were sensitive to tembotrione with higher intensity for the IAC - 125. The maximum quantum yield of photosystem II showed useful tool for studies of selectivity/phytotoxicity symptoms of herbicides used.
\end{abstract}

Keywords: Zea mays; herbicides; post-emergence; physiology

\section{Introduction}

Characteristics of quality have received increasing importance in popcorn breeding programs instead of agronomic characteristic. However, the plants are smaller,

Received: 19 March 2014 / Accepted: 8 April 2014 / Published online: 7 May 2014

(C) Horizon e-Publishing Group

CITATION

Freitas, I. L. J., Rodrigues, W. P., Amaral Júnior, A. T., Freitas, S. P., Amim, R. T., Vittorazzi, C \& Freitas, J. A. A. (2014). Maximum quantum yield of photosystem II to assist in the measurement of herbicide selectivity in popcorn. Plant Science Today, 1(2), 80-85. http://dx.doi.org/10.14719/pst.2014.1.2.28

AUTHORS' AFFILIATION

North Rio de Janeiro University, Campos dos Goytacazes, Rio De Janeiro, Brazil, 28013-602.

*CORRESPONDENCE: Ismael L. J. Freitas, Email: ismaelljf@yahoo.com.br with fewer leaves, narrow leaf blade, less vigour and slower initial growth when compared to those of corn hybrids (Silva et al., 2013). Thus, the new popcorn cultivars show lower competitive ability when growing under interference of the weed, if compared to corn hybrids (Jakelaitis, Silva, Silva, Ferreira, \& Vivian, 2005).

Due to the limited information about selective herbicides for popcorn cultivation, many farmers improperly use products registered for common corn, which may not be selective to some varieties of popcorn corn (Freitas et al., 2009).

Studies about selectivity of herbicides on popcorn hybrids are necessary. Often these studies are realized by traditional methods, observing intoxication symptoms of shoot and its correlation with biometric parameters. It is known that the technique of fluorescence of the chlorophyll $a$ can allow the identification of damage to the photosynthetic device with no visual symptoms, causing damages that can only be identified at harvest time.

The main variables observed in the fluorescence measurements of chlorophyll $a$ are: initial fluorescence, basal or minimal $\left(\mathrm{F}_{0}\right)$, which is the fluorescence when all reaction centers are opened; maximal fluorescence $\left(F_{m}\right)$, which is the fluorescence when all reaction centers are closed; variable fluorescence $\left(F_{v}\right)$, which is determined by the state of the reaction center (open or closed); efficiency or maximum quantum yield of photosystem II (PSII) $\left(F_{v} / F_{m}\right)$ and, performance index or performance (PI) (Strasser, Tsimilli-Michael, \& Srivastava, 2004). Leaves of healthy corn present $\mathrm{F}_{\mathrm{v}} / \mathrm{F}_{\mathrm{m}}$ values around 0.77-0.79 (Romero, Magalhães, Alves, Durães, \& Vasconcellos, 2003).

The UENF 14, BRS Angela and IAC 125 hybrid cultivars are materials that show high productivity and popping expansion, resistance to Exserohilum turcicum and are adapted to north and northwest of Rio de Janeiro State (Freitas et al., 2013). The action mechanism of the mesotrione is inhibition of carotenoid biosynthesis by interfering in the enzyme 4-hydroxyphenylpyruvate 
dioxygenase-(HPPD) activity in chloroplasts. The action mechanism of nicosulfuron is based on the inhibition Acetolacto Synthase (ALS), an essential enzyme in the biosynthesis of the branched chain amino acids (leucine, isoleucine and valine), a potent inhibitor of cell division. The tembotrione is HPPD inhibitor, thereby preventing the formation of carotene by inhibiting enzymes which catalyze the synthesis of carotene. The molecule presents translocation via apoplastic and is easily absorbed by the meristematic tissues of leaves and roots, accumulating in chloroplasts (Oliveira, 2011).

Thus, the aim of this study was to evaluate the selectivity/phytotoxicity of herbicides (mesotrione, nicosulfuron, and tembotrione) by means of the maximum quantum yield of PSII associated with the biometric analyzes.

\section{Materials and methods}

The experiment was conducted at the Research Support Unit of the Centro de Ciências e Tecnologias Agropecuárias in the Universidade Estadual do Norte Fluminense, following randomized block design in a factorial system $(3$ $x$ 4), with three replications. Three genotypes (BRS Angela, IAC-125 and UENF-14) and four management weed systems: control; mesotrione (192 $\mathrm{g} \mathrm{ha}^{-1}$ a.i.); tembotrione (120 $\mathrm{g} \mathrm{ha}^{-1}$ a.i.) and nicosulfuron (60 $\mathrm{g} \mathrm{ha}^{-1}$ a.i.). Each experimental unit consisted of four lines of length five meters spaced $1.0 \mathrm{~m}$ between lines and $0.2 \mathrm{~m}$ between plants, with a stand of 50,000 plants ha- ${ }^{-1}$. As useful areas, the two central lines were considered, disregarding $0.5 \mathrm{~m}$ from the ends of each line.The application of the herbicides was carried out when the popcorn plants were at the four leaves stage.

The characteristics evaluated were: a) number medium of ears of the corn (EN); b) grain yield, in kg ha-1 (GY); c) average weight of 100 grains, in $\mathrm{g}$ (P100); d) popping expansion, in $\mathrm{mL}^{-1}$ (PE); and e) measurements of chlorophyll $a$ fluorescence.

The EN was obtained by corn ears number per plot, on in the harvest. The GY was determined by the grains weight after removing the corn cob, expressed in $\mathrm{kg} \mathrm{ha}^{-1}$. As regards the P100, 100 grains, randomly taken of distinct plants of each plot, were weighed on balance to two decimal places. The PE was determined in laboratory with the aid of a precision balance. The 30 grains mass were measured and, using the microwave with the popping time of $1.45 \mathrm{~min}$, the popcorn expanded volume was determined in mL.g-1.

To evaluate the fluorescence of chlorophyll $a$, a modulated fluorometer (MINI-PAM Model - Walz, Germany) was used. Therefore, physiologically ripe and vigorous leaves of each plant completely expanded were employed. The initial fluorescence was obtained with low intensity modulated light $\left(<0.1 \mu \mathrm{mol} \mathrm{m}^{-2} \mathrm{~s}^{-1}\right)$ to induce no effect on variable fluorescence. The maximum fluorescence was determined with a saturating light pulse $(6,000 \mu \mathrm{mol}$ $\left.\mathrm{m}^{-2} \mathrm{~s}^{-1}\right) 0.3 \mathrm{~s}$, reproduced in the frequency of $600 \mathrm{~Hz}$, resulting in the closure of all PSII reaction centers. The fluorescence variable $\left(\mathrm{F}_{\mathrm{v}}\right)$ was determined by the difference between $F_{0}$ and $F_{m}$. With the values of $F_{v}$ and $F_{m}$, maximum photochemical efficiency $\left(\mathrm{F}_{\mathrm{v}} / \mathrm{F}_{\mathrm{m}}\right)$ was obtained. The values were obtained between 8:00 to 10:00 am, done on each one of the five repetitions, on each one of the treatments, up to $0,2,4,6,12$ and 18 days after the application of the treatments (DAA), making a total of six evaluations. Before the analyses of the fluorescence, the leaves remained pre-adapted to the dark during $30 \mathrm{~min}$, aiming to the complete oxidation of the components of the electrons transport system. Such adaptation, in fact, corresponds only to a circular area of the foliar blade, four millimeters in diameter size, achieved by using tweezers with a window system that allows its opening when measuring or its closing for adaption to the dark.

The data were submitted to joint variance analysis subdivided in time, being the plots represented by the treatments (cultivars) and the subplots represented by the management (herbicides), and average compared by Tukey Test at $5 \%$ probability. The computer resources of the software Genes (Cruz, 2013) were employed to achieve the statistical analysis.

\section{Results and Discussion}

Mesotrione caused reduction of photochemical efficiency in all the genotypes studied after the second evaluation (Fig. 1). The BRS Angela variety was the only one to reach values of photochemical efficiency similar to the control on the eighteenth day (Fig. 1A). The mesotrione inhibit carotenoid biosynthesis, interfering with the activities of the enzyme HPPD (4-Hydroxyphenylpyruvate dioxygenase) in the chloroplasts, causing bleaching with subsequent necrosis and plant tissues death in about one or two weeks (Mitchell et al., 2001). Johnson, Young, \& Matthews (2002) observed injuries to the maize plants seven days after the application of mesotrione, depending on the season and the dose applied.

The tembotrione caused reduction of $F_{v} / F_{m}$ in BRS Angela variety on the sixth day of evaluation, but it presented recovery on the eighth day of evaluation. In the IAC - 125 hybrid and in the UENF-14 variety, the value of $\mathrm{F}_{\mathrm{v}} / \mathrm{F}_{\mathrm{m}}$ did not change with the application of tembotrione during the period of evaluation, and, regarding the nicosulfuron, there was no change in the values of $\mathrm{F}_{\mathrm{v}} / \mathrm{F}_{\mathrm{m}}$ for any cultivars. 

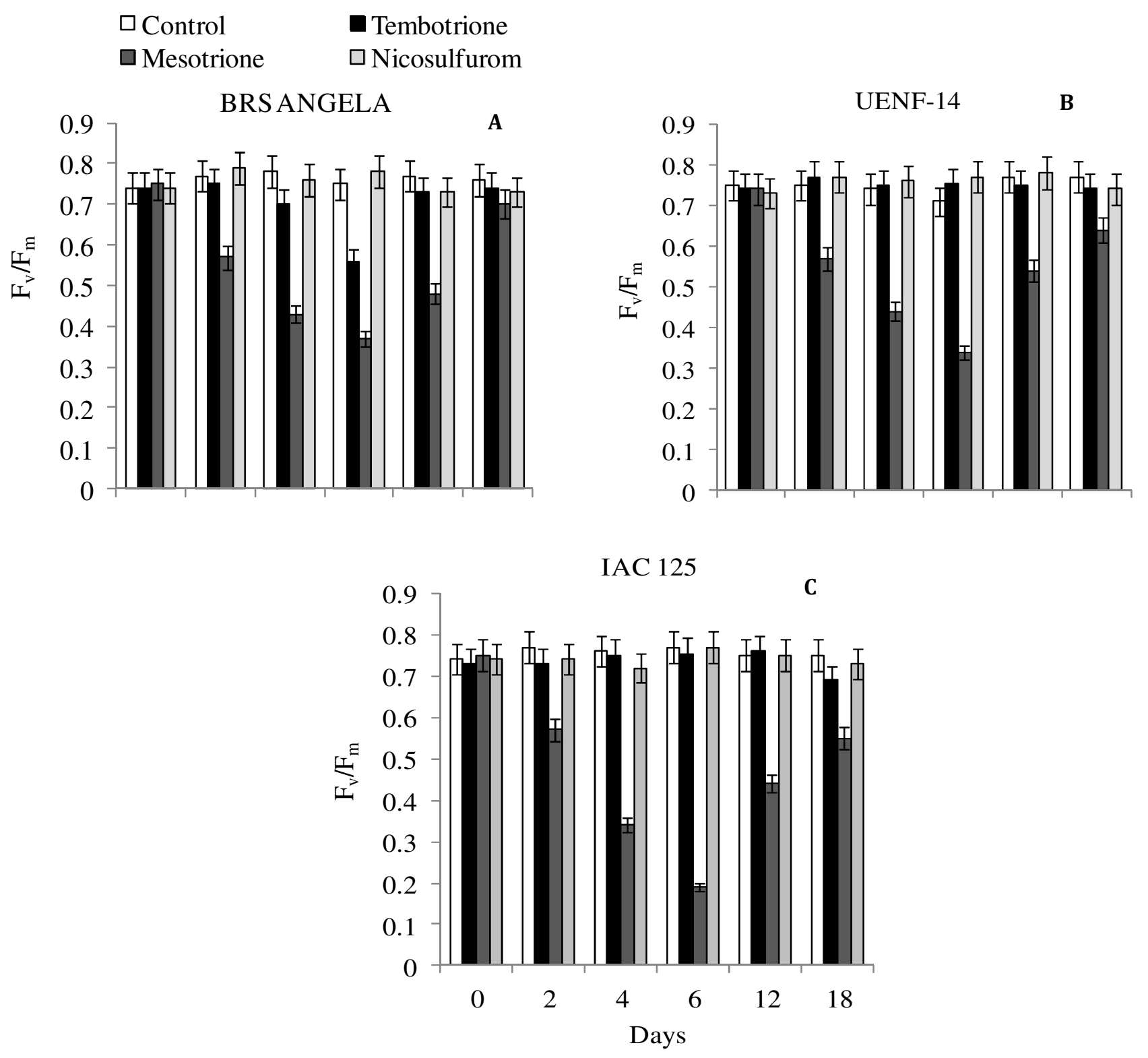

Fig. 1 - Photochemical efficiency of photosystem II (Fv/Fm) up to 18 days in BRS Angela (A), UENF-14 (B) and IAC 125 (C) popcorn cultivars submitted the application of tembotrione, mesotrione and nicolsufuron.

Freitas et al. (2009) observed that the tembotrione caused slight toxicity, in post-emergence, the more affected popcorn varieties were PA-038 (with 50\% of phytotoxicity) and Viçosa-Maringá (with 18,75\% phytotoxicity), but both presented fast recovery. Cavalieri et al. (2008) did not observe effect on productivity due to nicosulfuron in corn hybrids, noting however that some hybrids showed phytotoxicity symptoms occurring differential tolerance among these being necessary steps to evaluate this tolerance yield.

The carotenoids have an important role in the utilization of light and in the photoprotection of the photosystem complex. Several studies have proven that these compounds are very important to protect the photosynthetic organism from damages caused by excessive light, by the xanthophyll cycle (Ort, 2001). The violaxanthin is epoxidized to produce anteraxanthin and, finally, zeaxanthin. The latter participates intensively in the regulation of energy dissipation of PSII, when it has an overload of energy (Romero, Magalhães, Alves, Durães, \& Vasconcellos, 2003). That way, the studied cultivars reported a defence system less efficient to mesotrione than the others, demanding a period of 18 days for BRS Angela (Fig. 1A) and over 18 days for UENF-14 (Fig. 1B) and for IAC-125 (Fig. 1C), so that the cellular detoxification 


\section{$\square$ BRS ANGELA घUENF-14 पIAC 125}

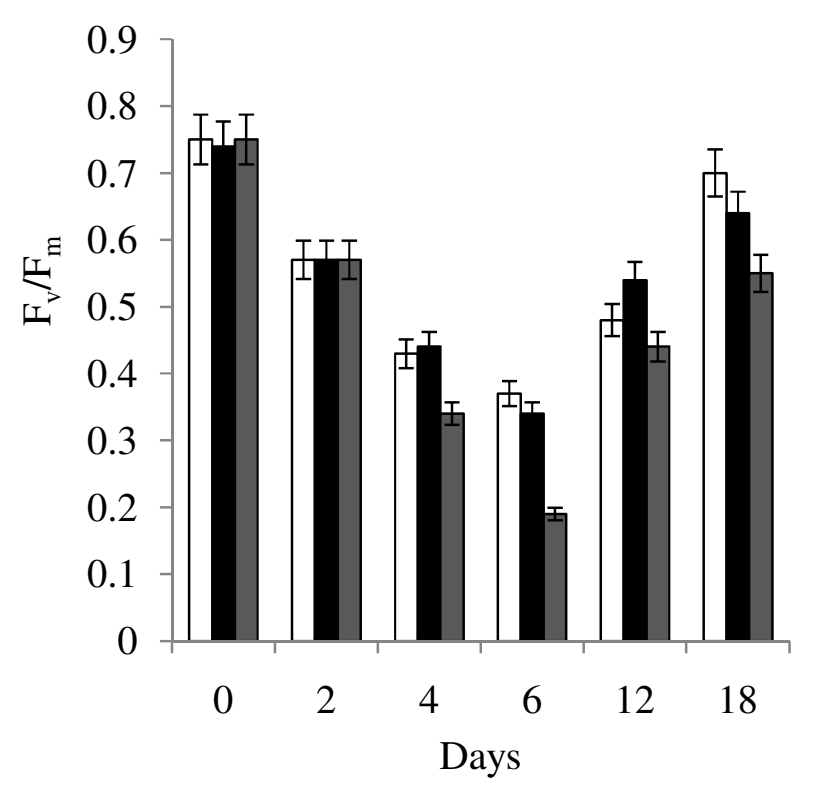

Fig. 2 - Photochemical efficiency of photosystem II (Fv / Fm) up to 18 days in BRS Angela, UENF-14 and 125 IAC popcorn cultivars submitted the application of mesotrione.

processes could occur. The difference among genotypes in this period can be linked to genetic factors.

When compared the genotypes in relation only to the mesotrione effects (Fig. 2), the BRS Angela and UENF-14 variety presented similar responses during the period of evaluation, while the IAC-125 hybrid presented lower values of $F_{v} / F_{m}$ after the fourth evaluation. The photochemical efficiency was more affected on the sixth day after the application of mesotrione, BRS Angela, UENF-14 and IAC-125 presented values of $F_{v} / F_{m}$ at around
$0.38,0.35$ and 0.19 , respectively. Leaves of healthy maize reported values of $\mathrm{F}_{\mathrm{v}} / \mathrm{F}_{\mathrm{m}}$ at around 0.77-0.79 (Romero et al., 2003).

With regard to biometric analysis, the effect of herbicide application was only significant for the grains weight while the genetic differences prevailed in the GY and in the PE. Considering the interaction genotype $\mathrm{x}$ handling (herbicide), there were significant differences only in the GY (Table 1).

Table 1 - Summary of the Analysis of Variance of the BRS Angela, IAC-125 e UENF-14 genotypes submitted to management with mesotrione, tembotrione and nicosulfuron herbicides.

\begin{tabular}{llllll}
\hline \multicolumn{7}{c}{} & \multicolumn{5}{l}{ SM } & P 100 & PE \\
\hline SV & DF & EN. & GY & $3.391^{* *}$ \\
Herbicide & 2 & $293.083^{\text {ns }}$ & $2766267.361^{* *}$ & $4.152^{* *}$ & $1.961^{\text {ns }}$ \\
Genotype & 3 & $123.287^{\text {ns }}$ & $4276871.296^{*}$ & $1.036^{\text {ns }}$ & $158.318^{*}$ \\
Herbicide*Genotype & 2 & $243.583^{\text {ns }}$ & $568502.083^{*}$ & $10.967^{\mathrm{ns}}$ & $4.281^{\text {ns }}$ \\
Residue & 6 & $138.398^{\text {ns }}$ & $172370.600^{*}$ & $0.989^{\text {ns }}$ & 0.946 \\
\hline Total & 22 & 189.053 & 109592.424 & 1.236 & - \\
\hline Average & 35 & - & - & - & 28.86 \\
Cv (\%) & & 51.08 & 2362.50 & 12.61 & 3.40 \\
\hline
\end{tabular}

* and ${ }^{* *}$ Significant at 1 and $5 \%$ probability, respectively.

NS - No significant. 
Table 2 - Average values of the number medium of ears of the corn (EN), grain yield (Kg ha-1), average weight of 100 grains (P100) and popping expansion (PE), resulting from the interaction between different genotypes and used handling.

\begin{tabular}{|c|c|c|c|}
\hline \multicolumn{4}{|l|}{ EN } \\
\hline Herbicide/Genotype & BRS-Angela & IAC-125 & UENF-14 \\
\hline Control & $45.00 \mathrm{Aa}$ & $49.00 \mathrm{Aa}$ & $46.67 \mathrm{Aa}$ \\
\hline Mesotrione & $59.33 \mathrm{Aa}$ & $46.33 \mathrm{Aa}$ & $47.67 \mathrm{Aa}$ \\
\hline Tembotrione & $55.33 \mathrm{Aa}$ & $57.33 \mathrm{Aa}$ & $38.67 \mathrm{Aa}$ \\
\hline Nicosulfuron & $64.00 \mathrm{Aa}$ & 48.67 Aa & $55.00 \mathrm{Aa}$ \\
\hline \multicolumn{4}{|l|}{ GY $\left(\mathrm{Kg} \mathrm{ha}^{-1}\right)$} \\
\hline Herbicide/Genotype & BRS-Angela & IAC-125 & UENF-14 \\
\hline Control & $2660.00 \mathrm{Aba}$ & $2830.00 \mathrm{Aa}$ & $2943.33 \mathrm{Aa}$ \\
\hline Mesotrione & 1263.33 Cab & $1213.33 \mathrm{Bb}$ & $1905.00 \mathrm{Ba}$ \\
\hline Tembotrione & 2308.33 Bab & $1748.33 \mathrm{Bb}$ & $2533.33 \mathrm{ABa}$ \\
\hline Nicosulfuron & $3160.00 \mathrm{Aa}$ & $2818.33 \mathrm{Aa}$ & $2966.67 \mathrm{Aa}$ \\
\hline \multicolumn{4}{|l|}{ P $100(\mathrm{~g})$} \\
\hline Herbicide/Genotype & BRS-Angela & IAC-125 & UENF-14 \\
\hline Control & $13.02 \mathrm{Aa}$ & $12.31 \mathrm{Aa}$ & $13.89 \mathrm{Aa}$ \\
\hline Mesotrione & $12.26 \mathrm{Aa}$ & $11.72 \mathrm{Aa}$ & $13.52 \mathrm{Aa}$ \\
\hline Tembotrione & $12.98 \mathrm{Aa}$ & $11.24 \mathrm{Aa}$ & $12.57 \mathrm{Aa}$ \\
\hline Nicosulfuron & $13.59 \mathrm{Aa}$ & $10.85 \mathrm{Aa}$ & $13.39 \mathrm{Aa}$ \\
\hline \multicolumn{4}{|l|}{$\mathrm{PE}$} \\
\hline Herbicide/Genotype & BRS-Angela & IAC-125 & UENF-14 \\
\hline Control & $25.00 \mathrm{Ac}$ & $33.11 \mathrm{Aa}$ & $27.77 \mathrm{Ab}$ \\
\hline Mesotrione & 26.44 Ac & $32.22 \mathrm{Aa}$ & $27.80 \mathrm{Ab}$ \\
\hline Tembotrione & $23.34 \mathrm{Ac}$ & $33.99 \mathrm{Aa}$ & $27.90 \mathrm{Ab}$ \\
\hline Nicosulfuron & $26.45 \mathrm{Ac}$ & $32.33 \mathrm{Aa}$ & $28.63 \mathrm{Ab}$ \\
\hline
\end{tabular}

Independent from the genotype used in this experiment, the EN was not altered through the application of herbicides (Table 2). However, the analysis of this variable, isolated, may not be satisfactory.

GY is one of the main characteristics to be sought in popcorn breeding programs. Comparing with control, IAC-125 and UENF-14 presented GY greater than BRS Angela, where the difference is related more directly by the adaptation to the region conditions and to genetic potential (Table 2) (Rangel, Amaral Júnior, Gonçalves, Freitas Júnior, \& Candido, 2011). The mesotrione caused a reduction of GY in BRS Angela, in IAC-125 and in UENF-14 of $110.5 \%, 133.24 \%$ and $54.50 \%$ respectively, on which UENF-14 reported lower reduction associated, probably, to genetic factors expressed in an attempt to minimize cellular damages (Table 2). The data highlight the damages caused to PSII, due to the inhibition of carotenoid synthesis, but the first 18 days of the plant growth (Fig. 1) are enough to reduce the GY.

The herbicide tembotrione caused reduction of GY in genotypes BRS Angela and IAC-125 of $15.23 \%$ and $61.87 \%$, respectively. This reduction in BRS Angela can be associated to the reduction of $\mathrm{F}_{\mathrm{v}} / \mathrm{F}_{\mathrm{m}}$, different from
IAC-125, on which this variable maintained similar to the control. The nicosulfuron did not report effect in GY, indicating that the studied cultivars present detoxification mechanisms to this herbicide, which are based on the different metabolic rates of these plants (Carey, Penner, \& Kells, 1997) and on the absorption and translocation rate for vegetables (Cavaleiri et al., 2008).

Tolerant species detoxify these herbicides very fast, turning them into non-phytotoxic compounds through the action of cytochrome P450 monooxygenases, in reactions of hydroxylation and glyoxylation (Fonne-Pfister, Gaudin, Kreuz, Ramsteiner, \& Ebert, 1990).

In this way, factors related to chemical reactions and/or to molecules changed during the metabolism and not related to photosystem I (PSI) and PSII involving tembobrione can contribute to reduce GY in the IAC-125.

The cultivars reported a similar performance to the P100 variable, independent from the application of herbicides. Timossi and Freitas (2011) also did not observe effects on the application of nicosulfuron in the 100 grains mass of the BRS 1035 hybrid.

The genetic divergences prevailed for the variable PE 
without the effect herbicides application, being cultivar IAC-125 reported better performance, followed by UENF-14 and BRS Angela, which presented lower performance. Vittorazzi, Amaral, Gonçalves, Candido, \& Silva (2013) observed a better performance for this variable in UENF-14 when compared to BRS Angela, corroborating with the data revealed in this study.

The data showed that the maximum quantum yield of the PSII can, early and with efficiency, identify the phytotoxicity caused by mesotrione in popcorn, and therefore can contribute to the studies of herbicide selectivity for popcorn. However, to increase the success of this tool, research is needed to indicate to what extent the damage caused in fotossintema II could influence the production for certain cultivars. In this study, a reduction of approximately 77\% and 51\% (sixth day) for IAC -125 and BRS Angela, respectively, were sufficient to decrease production. The quantum yield of Photosystem II was presented as a tool to study the selectivity/phytotoxicity of mesotrione, tembotrione and nicosulfuron in popcorn.

\section{Acknowledgments}

To Universidade Estadual do Norte Fluminense Darcy Ribeiro UENF , for making possible the realization of the experiment, to the Conselho Nacional de Desenvolvimento Científico e Tecnológico - CNPq for the financial support.

\section{References}

Carey, J. B., Penner, D., \& Kells, J. J. (1997). Physiological basis for nicosulfuron and primisulfuron selectivity in five plant species. Weed Science, Lawrence, 45, 22-30.

Cavalieri, S. D., Oliveira Junior, R. S., Constantin, J., Biffe, D. F., Rios, F. A., \& Franchini, L. H. M. (2008). Tolerância de híbridos de milho ao herbicida nicosulfuron1. Planta Daninha, Viçosa-MG, 26, 203-214.

Cruz, C. D. (2013). GENES - a software package for analysis in experimental statistics and quantitative genetics. Acta Scientiarum, 35, 271-276.

Freitas, I. L. J., Amaral Junior, A. T., Viana, A. P., Pena, G. F., Cabral, P. S., Vittorazzi, V., \& Silva, T. R. C. (2013). Ganho genético avaliado com índices de seleção e com REML/Blup em milho-pipoca. Pesquisa Agropecuária Brasileira, 48, 1464-1471

Freitas, S. P., Moreira, J. G., Freitas, I. L. J., Freitas Júnior, S. P., Amaral Júnior, A. T., \& Silva, V. Q. R. (2009). Fitotoxicidade de herbicidas a diferentes cultivares de milho-pipoca. Planta Daninha, 27, 1095-1103. doi:10.1590/S0100-83582009000500023

Fonne-Pfister, R., Gaudin, J., Kreuz, K., Ramsteiner, K., \& Ebert, E. (1990). Hydroxylation of primisulfuron by inducible cytochrome P450 dependent monooxygenase system from maize. Pesticide Biochemistry and Physiology, 37, 165-173., v. 37, n. 1, p. 165-173, 1990.

Jakelaitis, A., Silva, A. F., Silva, A. A., Ferreira, L. R. E., \& Vivian, R. (2005). Controle de plantas daninhas na cultura do milho-pipoca com herbicidas aplicados em pós-emergência. Planta Daninha, 23, 509-516. doi:10.1590/S0100-83582005000300015

Johnson, B. C., Young, B. G., \& Matthews, J. L. (2002). Effect of post emergence application rate and timing of mesotrione on corn (Zea mays) response and weed control. Weed Technology, 16, 414-420. doi:10.1614/0890-037X(2002)016[0414:EOPARA]2.0.CO;2

Mitchell, G., Bartlett, W. D., Fraser, T. E. M., Hawkes, T. R., Holt, D. C., Townson, J. K., \& Wichert, R. A. (2001). Technical Mesotrione: a new selective herbicide for use in maize. Pest Managment Science, 57, 120-128. doi:10.1002/1526-4998(200102)57:2<120::AID-PS254>3. $0 . \mathrm{CO} ; 2-\mathrm{E}$

Oliveira J. R., RS. (2011) Mecanismos de Ação de Herbicidas. In: Oliveira JR, RS; Constantin, J; Inoue, MH. (eds.). Biologia e manejo de plantas daninhas. Curitiba: Omnipax, p.141-192.

Ort, D. (2001). When there is too much light. Plant Physiology, 125, (1), 29 - 32. doi:10.1104/pp.125.1.29 PMid:11154289

Rangel, R. M., Amaral Júnior, A. T., Gonçalves, L. S., Freitas Júnior, S. P., \& Candido, L. S. (2011). Análise biométrica de ganhos por seleção em população de milho-pipoca de quinto ciclo de seleção recorrente. Revista Ciência Agronômica, 42, 473 481. doi:10.1590/S1806-66902011000200029

Romero, J. L., Magalhães, P. C., Alves, J. D., Durães, F. M., \& Vasconcellos, C. (2003). Efeito do cálcio sobre algumas características biofísicas e morfológicas de plantas de milho BRS-4154 submetidas ao alagamento do solo. Revista Brasileira de Milho e Sorgo, 3, (2), 172-181.

Silva, T. R. C., Amaral Júnior, A. T., Gonçalves, L. S. A., Candido, L. S., Vitorazzi, C., \& Scapim, C. A. (2013). Agronomic performance of popcorn genotypes in Northern and Northwestern Rio de Janeiro State. Acta Scientiarum. Agronomy, 35, 57-63.

Strasser, A., Tsimilli-Michael, M., \& Srivastava, A. (2004). Analysis of the fluorescence transient, In: Papageorgiou, G. C.; Govindjee (eds.), Chlorophyll fluorescence: A signature of photosynthesis. Advances in Photosynthesis and Respiration Series. Springer, Dordrecht, p. 32-362.

Timossi, P. C., \& Freitas, T. T. (2011). Eficácia de nicosulfuron isolado e associado com atrazine no manejo de plantas daninhas em milho. Revista Brasileira de Herbicidas, 10, 210-218.

Vittorazzi, C., Amaral, A. T. Jr., Gonçalves, L. S. A., Candido, L. S., Silva, T. R. C. (2013). Selecting pre-cultivars of popcorn maize based on nonparametric indices. Revista Ciência Agronômica 44, 356-362. Retrieved from http://www.redalyc.org/pdf/1953/195325760019.pdf

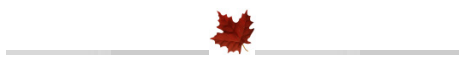

